\title{
WISSELING IN HET PAVILJOEN: PORSELEIN IN HET INTERIEUR
}

Voor de oktoberwisseling van voorwerpen in het Aziatisch Paviljoen is aansluiting gezocht met de hiervoor aangekondigde tentoonstelling Azië in Amsterdam. De band met Europa staat centraal, allereerst met een fraaie miniatuur die wordt toegeschreven aan Kesu Das (afb. 1). Deze kleine laat$16^{\mathrm{e}}$ eeuwse schildering had een Nederlandse prent van Hendrick Goltzius als voorbeeld (afb. 2), maar het is opvallend hoe de krachtige musculatuur van Goltzius is aangepast aan het Indiase schoonheidsideaal, dat zachtere rondingen en lijnen voorstaat. Dit soort kleine wijzigingen maakt uiteraard deel uit van het reizen van motieven en afbeeldingen naar een ander deel van de wereld, en is ook te zien bij de andere voorwerpen die deze keer worden getoond.

In de lange vitrine op de beneden vitrine hebben de kimono's plaatsgemaakt voor een rijke uitstalling van porselein, zowel Chinees als Japans. Een aantal stukken is geplaatst op houten meubelen die in Azië voor Europese afnemers zijn gemaakt en er staat ook een zogeheten 'stomme knecht'.

Afb. 1 (links)

Romeinse held, toegeschreven aan Kesu Das, gouache, 18,2 x 10,7 cm., India, ca. 1590-95, Rijksmuseum Amsterdam, inv.nr. RP-T-1993-33

Afb. 2

Titus Manlius Torquatus, Hendrick Goltzius (1558-1617), gravure, $36,8 \mathrm{x}$ $23,6 \mathrm{~cm}$., Haarlem, 1586, Rijksmuseum Amsterdam, inv.nr. RP-P-H-OB-101.336

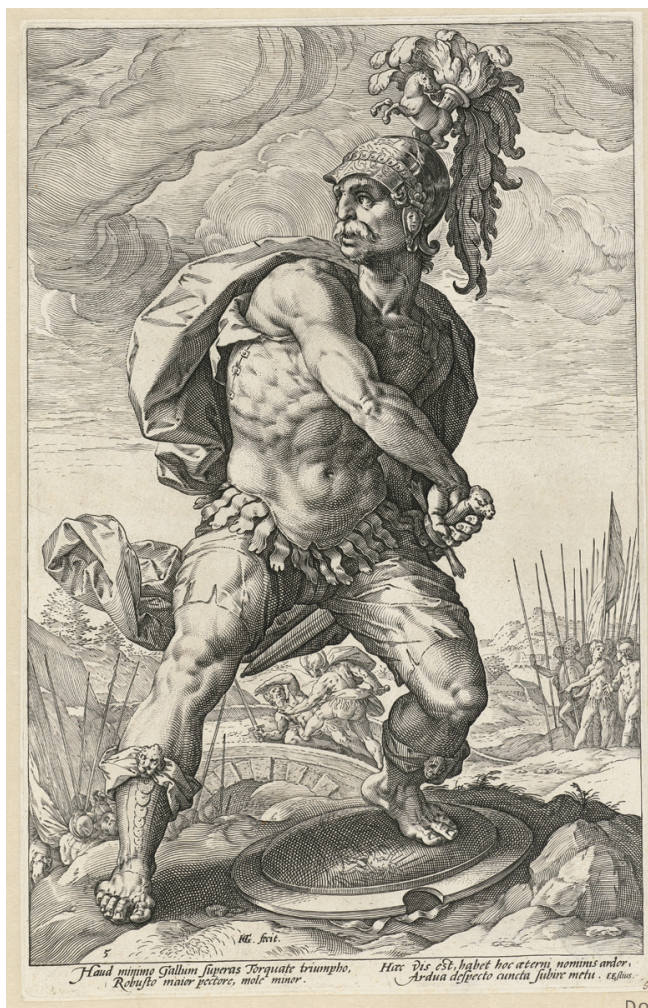


Dit merkwaardige voorwerp is een opeenstapeling van Japanse en Chinese borden en vazen, in de $19^{\mathrm{e}}$ eeuw gemaakt met behulp van als lakwerk en porselein versierde houten tussenstukken. Voor de gelegenheid is een aantal imposante stukken uit het depot gehaald. Zo zijn er de enorme vazen uit het bezit van Koning Willem I te zien. Zij werden in de $19^{e}$ eeuw ondergebracht in het Koninklijk Kabinet van Zeldzaamheden en gingen na de splitsing van het kabinet in 1883 naar het Nederlandsch Museum voor Geschiedenis en Kunst, de voorloper van het Rijksmuseum. Dergelijke vazen waren alleen weggelegd voor de bovenlaag van de bevolking en het was een technisch hoogstandje van de porseleinmakers in Jingdezhen om voorwerpen van een dergelijk groot formaat te kunnen maken. De Chinese porseleinindustrie was bijzonder hoogontwikkeld en kon desgewenst op bijna iedere mogelijke wens inspelen.

De Japanse porseleinmakerijen in Arita werkten op een veel kleinere schaal, maar konden toch ook goed voldoen aan de wensen van de markt. Dat is te zien in de kunstnijverheidsvitrine tegenover de uitstalling van vazen, waar twee theepotten met onderstellen staan, beide uit de $18^{\mathrm{e}}$ eeuw, uit Delft en Arita. Het Japanse exemplaar is duidelijk vervaardigd naar het Delfts voorbeeld: zowel versiering als vorm zijn vrijwel identiek en het is een voorrecht dat de Rijksmuseumcollectie beide stukken in bezit heeft. Overigens, alle stukken in deze opstelling komen voor in het volgend jaar te verschijnen Japandeel in de reeks boeken van het Rijksmuseum die de relaties van Nederland met een aantal landen beschrijft aan de hand van de Rijksmuseumcollecties. Hierin verschijnen in de komende tijd delen over Indonesië, China, India en Japan. 